\title{
Multidisciplinary team of oncology and the participation of speech therapy in the rehabilitation of patients subject to head and neck surgery
}

\author{
Equipe multidisciplinar de oncologia e a participação da fonoaudiologia na reabilitação de pacientes \\ sujeitos à cirurgia de cabeça e pescoço
}

\author{
Joab de Souza Arouche" ${ }^{*}$ \\ Universidade Federal do Amazonas, Manaus, Amazonas, Brasil. *Autor para correspondência. E-mail: \\ arouchejoab16@gmail.com
}

\begin{abstract}
Introduction: The main causes for the appearance of tumors in the head and neck are related to smoking and alcohol consumption. Emphasizing that smoking is the biggest risk factor for head and neck cancer, as well as lung and esophageal cancer. Among the most common neoplasms of the head and neck are those located in the oral cavity, pharynx and larynx and, according to the degree of these lesions, resections can be total or partial and often associated with chemotherapy, radiotherapy or even by isolated actions. Functions such as chewing, swallowing, speech and voice end up being compromised and are essential for survival and social life. Given the facts, this research aimed to carry out scientific research on the performance of the Speech-Language Pathologist in the multidisciplinary team for the rehabilitation of patients with head and neck cancer. Review: The most common cases of neoplasms are in the oral cavity (40\%), pharynx (15\%) and larynx (25\%). The speech therapist is the professional responsible for evaluating, rehabilitating and diagnosing possible changes that compromise the functions of the stomatognathic system. The main objective of the point of reflection is that the multiprofessional team aims to implement measures that contribute to the prevention of oncological diseases and the promotion/recovery of health. Discussion: As a result of this research, it was observed the importance of Speech Therapy in the treatment of patients submitted to head and neck resections, being included in a multidisciplinary team. Final considerations: In view of these facts, it is possible to highlight the relevance of speech therapy activities with cancer patients, both in the pre-surgical period, with guidance on surgery and possible speechlanguage changes, and in the post-surgical period, with the rehabilitation of stomatognathic functions. Emphasizing that effective results require interventions in conjunction with other head and neck specialists.
\end{abstract}

Keywords: speech therapy, multidisciplinary team, head and neck resections.

Resumo: Introdução: As principais causas para o aparecimento de tumores na região da cabeça e pescoço estão relacionadas ao tabagismo e ao consumo de álcool. Enfatizando que o tabagismo é o maior fator de risco para o câncer de cabeça e pescoço, bem como câncer de pulmão e esôfago. Entre as neoplasias mais comuns da cabeça e pescoço estão as localizadas na cavidade oral, faringe e laringe e, de acordo com o grau dessas lesões, as ressecções podem ser totais ou parciais e frequentemente associadas à quimioterapia, radioterapia ou mesmo por ações isoladas. Funções como mastigação, deglutição, fala e voz acabam sendo comprometidas e são essenciais para a sobrevivência e a vida social. Diante dos fatos, esta pesquisa teve como objetivo realizar um estudo científico sobre a atuação do Fonoaudiólogo na equipe multidisciplinar de reabilitação de pacientes com câncer de cabeça e pescoço. Revisão: Os casos mais comuns de neoplasias são na cavidade oral (40\%), faringe (15\%) e laringe (25\%). O fonoaudiólogo é o profissional responsável por avaliar, reabilitar e diagnosticar possíveis alterações que comprometam as funções do sistema estomatognático. O principal objetivo do ponto de reflexão é que a equipe multiprofissional tenha como objetivo implementar medidas que contribuam para a prevenção de doenças oncológicas e a promoção/recuperação da saúde. Discussão: Como resultado desta pesquisa, observou-se a importância da Fonoaudiologia no tratamento de pacientes submetidos a ressecções de cabeça e pescoço, sendo incluída em uma equipe multidisciplinar. Considerações finais: Diante desses fatos, é possível destacar a relevância das atividades fonoaudiológicas com pacientes oncológicos, tanto no período pré-cirúrgico, com orientações sobre cirurgia e possíveis alterações fonoaudiológicas, quanto no pós-cirúrgico, com a reabilitação das funções estomatognáticas. Enfatizando que resultados efetivos requerem intervenções em conjunto com outros especialistas em cabeça e pescoço.

Palavras-chave: fonoaudiologia, equipe multidisciplinar, ressecções de cabeça e pescoço. 


\section{Introduction}

Cancer is the third disease that causes the most deaths and limitations in the world (Kligerman, 2002; Wünsch \& Mongau, 2002). Among the most common neoplasms of the head and neck are those located in the oral cavity, pharynx and larynx and, according to the degree of these lesions, resections can be total or partial and often associated with chemotherapy, radiotherapy or even isolated actions (Oliveira et al., 2005).

The main causes for the appearance of tumors in the head and neck are linked to smoking and alcohol consumption. Emphasizing that smoking is the biggest risk factor for head and neck cancer, as well as lung and esophageal cancer. Oral neoplasia presents the most clinical cases. Given these facts, collective epidemiological interventions are necessary through public actions, in order to reduce the notification rate, as well as raise awareness about the risks and causes of cancer, in addition to promoting the monitoring of affected patients, rehabilitating their orofacial functions (Silva, Dornelas, Freitas, \& Ferreira, 2016).

Head and neck resections cause numerous mutilations, compromising the functions of the stomatognathic and phonatory system. Functions such as chewing, swallowing, speech and voice end up being compromised and are essential for survival and social coexistence. Hence the importance of including a specialist in orofacial motricity in the multidisciplinary team, in this case a speech therapist to rehabilitate or even adapt the compromised functions, thus promoting a better quality of life for individuals who have suffered head and neck resections. For the follow-up of these patients, joint interventions between several professionals are required (interdisciplinarity/multidisciplinary) and the speech therapist is one of them (Defina, Massih, \& Mamede, 2004). Given the facts, this research aimed to carry out scientific research on the performance of the Speech Pathologist in the multidisciplinary team for the rehabilitation of patients with head and neck cancer.

\section{Review}

\section{Head and neck cancer}

Head and neck carcinoma is the fifth most common cancer in the world (Colombo \& Rahal, 2009). The most common cases of neoplasms are in the oral cavity (40\%), pharynx (15\%) and larynx (25\%); however, there are other percentages on smaller scales for other regions of the head and neck, such as the floor of the mouth, palate and hyoid. These pathologies are more frequent in men, but there are several cases in women. The alterations compromise the functions of the stomatognathic system, such as chewing, swallowing, speech, phonation and voice. As in other neoplasms, cancer in the head and neck also has metastases in the regional lymph nodes responsible for the proliferation of the pathology to other structures and approximate organs.

The main etiological factors for the appearance of head and neck cancer are smoking and alcohol. There are also other risks, such as environmental pollution, exposure to chemical agents, malnutrition, genetics and poor dental hygiene. The treatment of neoplasms in the head and neck region can be isolated (chemotherapy/radiotherapy) or associated (chemotherapy/radiotherapy/surgery). Monitoring is performed by a multidisciplinary team (speech therapist, doctor, nutritionist, psychologist, social worker, dentist and physiotherapist).

\section{Speech therapy and oncology}

Speech therapy is the science that studies human communication and all the organs connected to this function. The speech therapist is the professional responsible for evaluating, rehabilitating and diagnosing possible changes that compromise the functions of the stomatognathic system. The assessment and rehabilitation of swallowing disorders in patients undergoing head and neck resections are also the competence of this professional (Freitas \& Zica, 2019). On the other hand, we have Cancerology, also called oncology, is the medical specialty that studies cancer and the way these diseases develop in the body, seeking treatment. Actions for the treatment of cancer patients are carried out jointly among these sciences, where each has its main role within its professional competence. Oncology focused on head and neck neoplasms aims to diagnose and seek the best treatment for pathologies hosted in this region that may or may not be associated (Theobald et al., 2016).

\section{Oncological multidisciplinary team}

Cancer is a pathology that, if left untreated, can compromise the entire organism (structure/function). For this reason, joint action between several professionals is extremely important (INCA, 2017). The main objective of the point of reflection is that the multiprofessional team aims to implement measures that contribute to the prevention of oncological diseases and the promotion/recovery of health. Therefore, one 
cannot imagine isolated acts in the treatment of cancer patients without the presence of a multidisciplinary team, whether in the inpatient or outpatient units. This team still works in accordance with the legislation of the Federal Councils of their respective professions, regulatory bodies for the exercise of the profession in Brazil. Each professional will contribute their professional skills; the most common professionals are speech therapist, oncology surgeon, dental surgeon, head and neck surgeon, nursing, psychologist, physiotherapist, clinical oncologist, among others.

We chose to perform a bibliographic review by searching the SciELO and GOOGLE ACADEMIC online databases with the following descriptors: head and neck cancer, speech therapy applied to oncology and also a multidisciplinary oncology team. Books were also consulted to collect information about the performance of the speech therapist in patients undergoing head and neck surgery and their participation in the multidisciplinary head and neck oncology team. 100 scientific papers were found and 83 were selected between 2000 and 2019 because they are directly linked to the objective of this research and because they are more recent, the rest were excluded. Five books were used in the context of this work. All selected articles were verified in detail page by page, and then the values found were tabulated.

\section{Discussion}

As a result of this research, it was observed the importance of Speech Therapy in the treatment of patients submitted to head and neck resections, being included in a multidisciplinary team. The team includes the head and neck surgeon who is the professional responsible for the diagnosis, the radiotherapist responsible for radiation treatment, the clinical oncologist responsible for monitoring the patient, the nurse with drug therapy, the physiotherapist who works with respiratory functions, nutritionist responsible for pre and postsurgical diets, dental surgeon responsible for taking care of oral health, psychologist responsible for socializing and introducing the patient into his new way of life, social worker responsible for the resources destined to the patient and their families and the speech therapist who rehabilitates and adapts the compromised stomatognathic functions (chewing, speech, voice, swallowing) (Cervantes, 2000). The inclusion of speech therapy in the oncology team is so important that there are several published works with the participation of speech therapists in the rehabilitation of patients undergoing numerous head and neck surgeries. According to Table 1.

Table 1. Bibliographic survey of several works that include articles, books and chapters that cited speech therapy activities with patients undergoing head and neck surgery.

\begin{tabular}{ccc}
\hline TUMOR & SURGERY & N $^{\circ}$ PUBLICATIONS \\
\hline Lip & Lip resections & 5 \\
Larynx & Total laryngectomy & 46 \\
Larynx & Partial laryngectomy & 2 \\
Larynx & Quasi-total laryngectomy & 3 \\
Tongue & Glossectomy & 11 \\
Jaw & Mandibulectomy & 3 \\
Palate & Palate resections & 2 \\
Retromolar area & Retromolar resections & 2 \\
Floor of the mouth & Pelvectomy & 3 \\
Central nervous system & & 1 \\
Associated structures & Pelveglossomandibulectomy & 3 \\
Cerebral neoplasms & & 1 \\
Associated structures & Pelveglossectomies & 1 \\
YEAR: $2000-2019$ & TOTAL & 83 \\
\hline
\end{tabular}

Table 1 shows that the laryngectomized patients were the ones who received more speech therapy assistance, this search is due to the fact that the surgery directly affects communication, because in most cases the larynx is completely removed causing loss of voice. Laryngeal cancer has the highest incidence among head and neck cancers (Figueiredo et al., 2019). Laryngectomies are divided into total and partial according to the degree of the lesion. The speech therapist in these cases presents the possible alternatives for a new means of communication that can be the electronic larynx, the tracheoesophageal prostheses and the esophageal voice, in addition to advising on hygiene in this region (Carmo, Camargo, \& Nemr, 2006; Carvalho, 2000). 
Glossectomy ranks second. This procedure can be total or partial, depending on the extent of the injury. The speech therapist in these cases applies adaptive methods for swallowing, speech and voice, as in most cases the patient has dysphagia, as the tongue is responsible for directing food to the oropharynx and, consequently, to the esophagus, speech is altered and voice undergoes resonance changes (Vieira, 2011).

Lip surgeries have become more frequent and the cancer-causing factor in this region is the use of alcohol, cigarettes and exposure to the sun, interventions ranging from partial to total, which can be on the lip commissures, on the lower and upper lips (Ribeiro et al., 2015). This neoplasm can compromise other structures, such as the palate, gums, tongue and floor of the mouth. The speech therapist in these cases promotes speech adaptation, muscle extension and salivary control (sialorrhea). The other head and neck neoplasms shown in the table above are less frequent, but, not least, the care and precautions must be the same in comparison with the others. In the general context, the speech therapist will promote a better quality of life for patients with head and neck cancer. Their knowledge is applied before surgery with instructions on the intervention and possible sequelae and in the postoperative period with the adaptation or rehabilitation of functions.

The structures that make up the stomatognathic apparatus are the tongue, the teeth, the jaw, the maxilla, the nasal cavities, the hard and soft palate and the muscles of the mouth (Angelis, 2000). Partial or total removals of these structures cause dysphagia, dysphonia, odynophagia, speech disorders, trismus, facial paralysis, hypertrophy, dyspnea and aphonia.

Surgical interventions frequently applied are glossectomy, resection of the palate, both hard and soft, pelvectomy, mandibulectomies, lip resections, laryngectomies and retromolar interventions. However, there are removals of associated structures when cancer through metastases evolves and compromises adjacent organs and structures, these procedures according to location are given the following names: glossomandibulectomy when the neoplasm is lodged in the tongue and jaw, requiring total or partial resection of these structures, pelveglossomandibulectomy referring to a lesion on the floor of the mouth, tongue and jaw, with total or partial removal of these structures and palate on the palate, tongue and jaw, among other interventions.

The techniques and protocols applied by speech therapists for the rehabilitation and adaptation of patients with communication disorders are scientifically evidenced. The resources frequently used by these professionals are: laser therapy, head and neck maneuvers, dressings, cryotherapy, electro-stimulation, therapeutic ultrasound, kinesiotherapy, specific protocols and orofacial exercises through isotonic, isometric and isokinetic maneuvers, according to each patient. For a favorable prognosis, joint actions with other professionals are necessary, where each one will have their clinical view of each case addressed.

\section{Final considerations}

From the data obtained, the importance of multidisciplinary monitoring was verified. Given these facts, it is possible to highlight the relevance of speech therapy activities with cancer patients, both in the pre-surgical period, with guidance on surgery and possible speech-language changes, and in the post-surgical period, with the rehabilitation of stomatognathic functions. Emphasizing that effective results require interventions in conjunction with other head and neck specialists.

\section{Acknowledgment}

The authors thank and dedicate this work to all speech therapy students and to all speech therapists in the State of Amazonas, especially those who are in Manaus.

\section{References}

Angelis, E. C. 2000. Fonoaudiologia na reabilitação do câncer de boca. In O. P. Junior (Org). Câncer de boca: aspectos básicos e terapêuticos. São Paulo, SP: Sarvier.

Carmo, R. D., Camargo, Z., \& Nemr, K. 2006. Relation between life quality and self-perception of vocal quality in total laryngectomized patients: pilot study. Revista CEFAC, 8, 518-528.

Carvalho, M. P. 2000. Atualidades em cabeça e pescoço: Câncer da cavidade oral. In A. P. B. Barros, L. Arakawa, M. D Tonini, \& V. A. Carvalho (Orgs.). Fonoaudiologia em Cancerologia. São Paulo, SP: Fosp.

Cervantes, O. 2000. O câncer de cabeça e pescoço e a equipe multidisciplinar. In A. P. B. Barros, L. Arakawa, M. D Tonini, \& V. A. Carvalho (Orgs.). Fonoaudiologia em Cancerologia. São Paulo, SP: Fosp. 
Colombo, J., \& Rahal, P. 2009. Alterações genéticas em câncer de cabeça e pescoço. Revista Brasileira de Cancerologia, 55(2): 165-174.

Defina, A. P., Massih, D. A., \& Mamede, R. C. M. 2004. Relato de experiência da atuação da fonoaudiologia e da psicologia a pacientes com câncer de cabeça e pescoço. Revista Brasileira de Cirurgia de Cabeça e Pescoço, $33(1), 45-48$.

Figueiredo, I. C., Vendramini, S. H. F., Lourenção, L. G., Sasaki, N. S. G. M. D., Maniglia, J. V., Padovani Junior, J. A., ... \& Santos, M. D. L. S. G. 2019. Profile and speech-language rehabilitation of patients with laryngeal cancer. CoDAS, 31(1), 2019.

Wünsch Filho, V., \& Moncau, J. E. 2002. Mortalidade por câncer no Brasil 1980-1995: padrões regionais e tendências temporais. Revista da Associação Médica Brasileira, 48(3), 250-257.

Freitas, A. S., \& Zica, G. M. 2019. Eficiência da deglutição na laringectomia parcial horizontal: pensando além da segurança. Distúrbios da comunicação, 31(3): 529-531.

Instituto Nacional de Câncer [INCA]. 2017. Estimativa 2018: incidência de câncer no Brasil / Instituto Nacional de Câncer José Alencar Gomes da Silva. Coordenação de Prevenção e Vigilância. Disponível em: http://www1.inca.gov.br/rbc/n_64/v01/pdf/15-resenha-estimativa-2018-incidencia-de-cancer-nobrasil.pdf. Acesso em: 15/12/2019.

Kligerman, J. 2002. Estimativas sobre a incidência e mortalidade por câncer no Brasil: 2002. Revista Brasileira de Cancerologia, 175-179.

Oliveira, I. B., Servilha, B. B., Ferreira, L. A., da Silva Bastos, T., de Oliveira Freire, V., \& Chagas, J. F. S. 2005. Qualidade de vida de pacientes pós-cirúrgicos de tumores malignos da cabeça e pescoço. Revista de Ciências Médicas, 14(6), 523-528.

Ribeiro, I. L. A., Medeiros, J. J. D., Rodrigues, L. V., Valença, A. M. G., Neto, L., \& de Andrade, E. 2015. Factors associated with lip and oral cavity cancer. Revista Brasileira de Epidemiologia, 18, 618-629.

Silva, E. G. F., Dornelas, R., Freitas, M. C. R., \& Ferreira, L. P. 2016. Pacientes com câncer de laringe no Nordeste: intervenção cirúrgica e reabilitação fonoaudiológica. CEFAC, 18(1), 151-157.

Theobald, M. R., Santos, M. L. D. M. D., Andrade, S. M. O. D., \& de-Carli, A. D. 2016. Percepções do paciente oncológico sobre o cuidado. Physis: Revista de Saúde Coletiva, 26(4), 1249-1269.

Vieira, C. A. 2011. Speech therapy in total glossectomy-case study. Revista da Sociedade Brasileira de Fonoaudiologia, 16(4), 479-482.

\section{Minicurrículo}

Joab Arouche. Speech Therapist (UNINORTE), Specialist in Collective Health with emphasis on Head and Neck Surgery (UCAM), Master in Science and Materials Engineering (UFAM), reviewer of projects submitted to the research development agency (FAPEAM), reviewer National journals and researcher in the nanostructured polymers laboratory (NANOPOL-UFAM).

\footnotetext{
Como citar: Arouche, J.S. 2020. Multidisciplinary team of oncology and the participation of speech therapy in the rehabilitation of patients subject to head and neck surgery. Pubsaúde, 3, a033. DOI: https:// dx.doi.org/10.31533/pubsaude3.a033

Recebido: 2 mai. 2020.

Revisado e aceito: 6 mai. 2020.

Conflito de interesse: os autores declaram, em relação aos produtos e companhias descritos nesse artigo, não ter interesses associativos, comerciais, de propriedade ou financeiros que representem conflito de interesse.

Licenciamento: Este artigo é publicado na modalidade Acesso Aberto sob a licença Creative Commons Atribuição 4.0 (CC-BY 4.0).
} 